\title{
Unusual flood events from an Alpine glacier: observations and deductions on generating mechanisms
}

\author{
J. WARBURTON \\ Department of Geography, University of Leicester, Leicester LE1 7RH, England \\ C. R. FENN \\ Hydrology and Modelling Section, Southern Science Ltd, Worthing, West Sussex BN11 2EN, England
}

\begin{abstract}
Observations are presented on a particularly unusual sequence of flood events witnessed at Bas Glacier d'Arolla, Switzerland, in July 1987. The sequence was triggered by heavy rain storms, and involved a supraglacial "overflow event" (water cascading from moulins over the snout of the glacier) succeeded, following a series of "mini-floods", by a subglacial "outburst event". Available hydrological and geomorphological data are used to assess the significance of the floods and to deduce likely explanations for each phase of the flood-event sequence. Bottom-up surcharging of a poorly developed subglacial drainage system is the preferred explanation for the overflow event. The subglacial outburst is explained as an extreme "spring event". Hydraulic jacking is implicated, but not proven, during both events. Whilst the flood sequence was triggered by an intense storm, englacially stored waters are believed to have contributed most of the flood waters.
\end{abstract}

\section{INTRODUCTION}

In mid-July 1987, a series of heavy rain storms caused flooding which wreaked severe damage across a broad swathe of the Western Alps. Naef and others (1989) have documented the geomorphological impacts of the storms in the Swiss Alps, and Rey and Dayer (1990) have assessed the influence of the storms on the operations of the Grande Dixence S.A. Hydro-Power Company in the Zermatt and Hérens valleys of Valais, Switzerland. This paper focuses on the characteristics and impacts of the unusual sequence of glacier floods which the storms triggered in the catchment of Bas Glacier d'Arolla, in Val d'Hérens, Switzerland, from 15 to 19 July 1987 . During these $4 \mathrm{~d}$, flood flows occurred first as a large, shortduration spill over the snout of the glacier, then as a series of "mini-floods" from previously unused marginal channels and, finally, as a large flood from the main portal stream. An estimated $22 \%$ of the annual total sediment load was conveyed in the $4 \mathrm{~d}$ of the flood period, in the ratio $44 \%$ suspended load, $56 \%$ bed load (Warburton, 1990).

Here, we describe the characteristics of the flood events as they were observed in the field, and discuss the hydrological and hydraulic circumstances implied. Our purpose is three-fold. First, to report the occurrence of a further - and particularly unusual - sequence of glacier flood behaviour from a glacier featured in Haeberli's (1983) review of flood-prone Swiss glaciers. Secondly, to attempt to explain how flood events of such unusual characteristics were generated. Because of the extreme and unpredictable nature of the events, we are unable to subject our working hypotheses to critical testing (we did not have an event-designed measurement framework in place). We are instead forced to advance preferred (rather than definitive) explanations, based on fitting theory to those measurements we were able to make

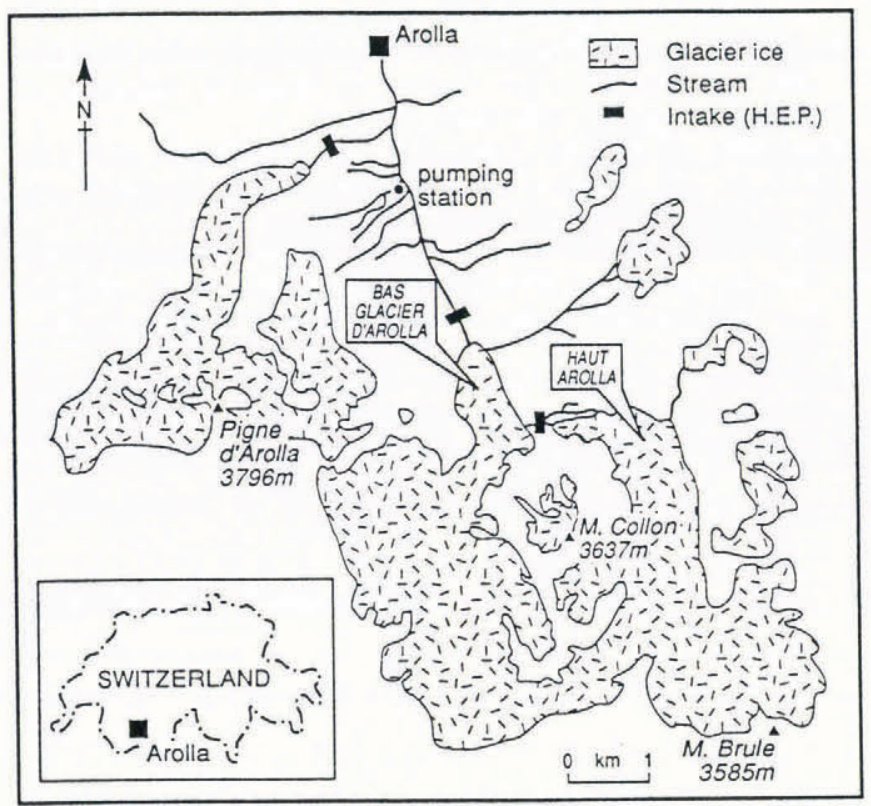

Fig. 1. Location map showing Bas Glacier d'Arolla. Discharge is gauged at the meltwater intake shown on the map. The natural drainage areas for Bas Glacier d'Arolla and Haut Glacier d'Arolla are 25.1 and $11.7 \mathrm{~km}^{2}$, respectively. 


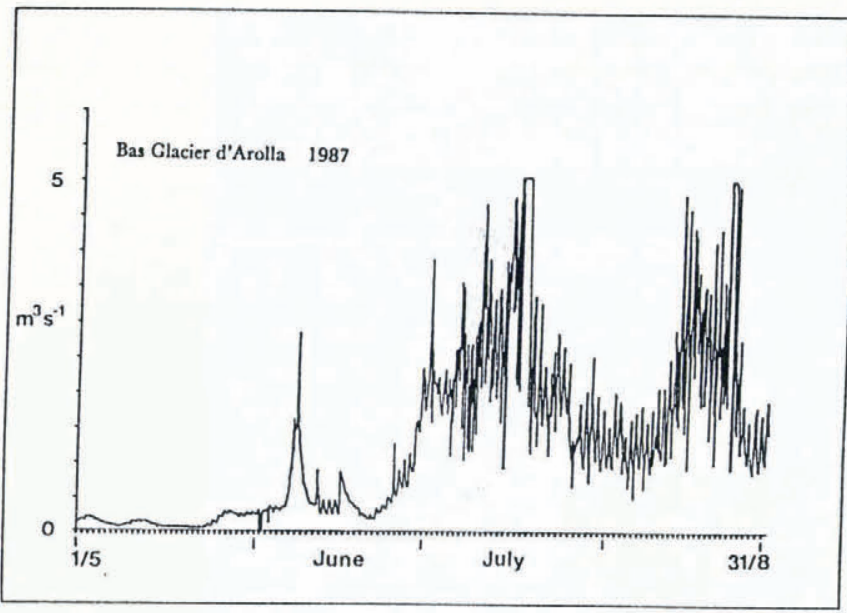

Fig. 2. Hydrograph of discharge from Bas Glacier d'Arolla during the 1987 ablation season. Note the low discharges prior to mid-July and the floods of 15-19 July. The large flood of August 1987 was caused by the release of water from the galleries of the Haut Glacier d'Arolla section of the Grande Dixence hydro-electric scheme (personal communication from $R$. Chevally).
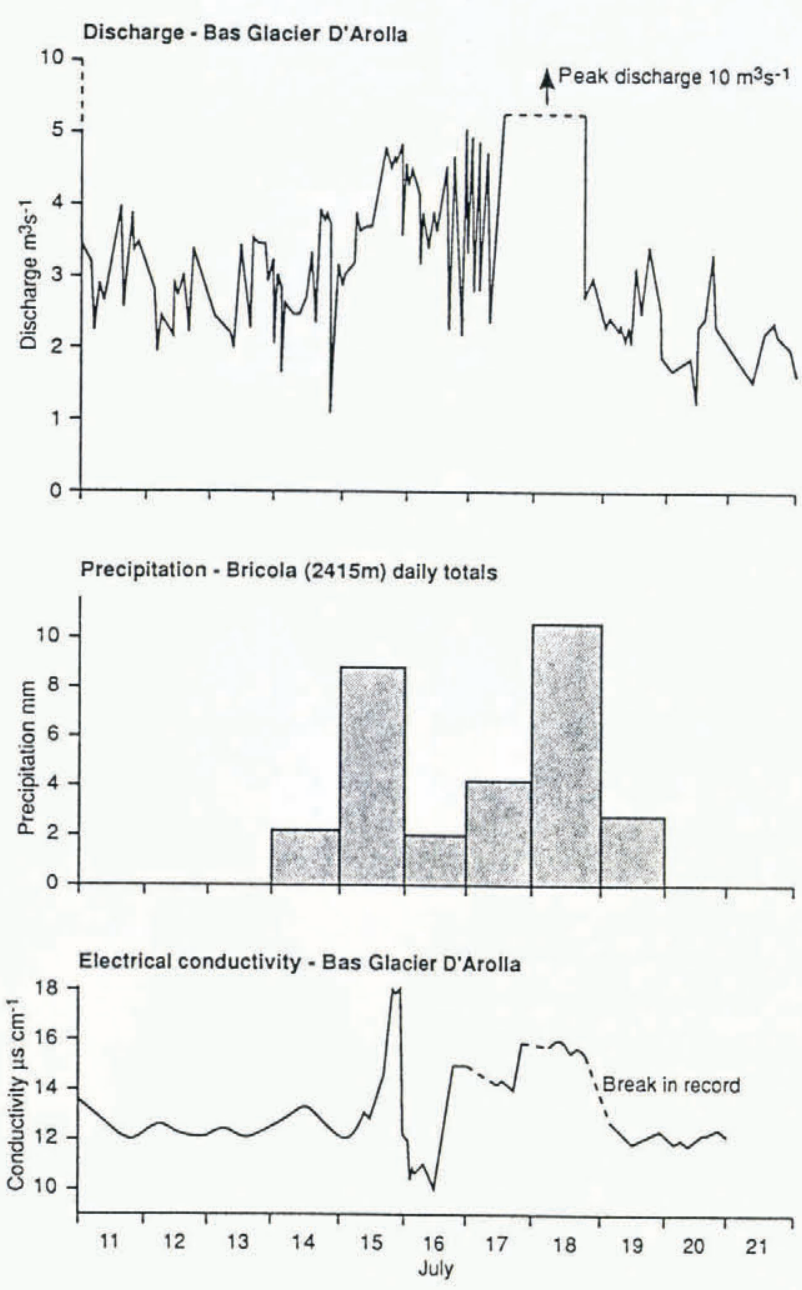

Fig. 3. Hydrological series at Bas Glacier d'Arolla for the period 11-21 July 1987. Discharge and electrical conductivity were measured in the main stream approximately $300 \mathrm{~m}$ from the snout. Rainfall was measured at Bricola $(2415 \mathrm{~m})$. Peak discharge was estimated using a simple "weir and float" method. during and after the floods (and to those we made- for other purposes - prior to the floods). Our third purpose, arising from these difficulties, is to present a case for "judgemental testing". Such an approach is sometimes necessary; floods (and other extreme events) are, after all, often indifferent to the needs of the critical rationalist. With this latter objective in mind, the paper is arranged into sections dealing, in turn, with (1) observations, (2) central question, (3) relevant theory, (4) preferred explanations, and (5) conclusions.

\section{OBSERVATIONS}

\section{Observations on the flood events of 15-19 July 1987}

This section presents observations on flow discharge, sediment transport and channel changes during the floods of 15-19 July 1987 at Bas Glacier d'Arolla. Figure 1 is a location diagram. Figure 2 shows the 1987 ablation season hydrograph of flows from the glacier. Figure 3 shows discharge, rainfall and electrical conductivity measurements for the period 11-21 July 1987. Figure 4 shows oblique photographs (taken during the July flood period) of the glacier tongue and proglacial zone. Figure 5 shows plan maps of the proglacial stream network at various times before, during and after the flood sequence. Stream flow is gauged at the meltwater intakes. Discharges up to $5 \mathrm{~m}^{3} \mathrm{~s}^{-1}$ are estimated from a stagedischarge relationship measured in a rectangular concrete channel. Flows in excess of $5 \mathrm{~m}^{3} \mathrm{~s}^{-1}$ are poorly documented as a proportion of the discharge is routed away from the gauged section. Peak discharges are therefore estimated in the main channel using a weir-and-float technique which is likely to have large errors associated with it. The record of precipitation shown in Figure 3 is based on measurements at the Bricola weather station, which is located in an adjacent valley $8 \mathrm{~km}$ distant and $275 \mathrm{~m}$ higher than Bas Glacier d'Arolla. Local estimates of precipitation provide an incomplete record of rainfall totals, and comparison between precipitation and discharge values over the short time-scale of the flood events is difficult. Air temperature was also recorded at Bricola but its relevance to the study site is thought to be very poor.

\section{Before the floods}

Prior to mid-July 1987, run-off from Bas Glacier d'Arolla had been weak (Fig. 2). The transient snow line was at a lower elevation than is normal for the time of year, and supraglacial and englacial drainage channels were poorly developed. Water levels in moulins were observed to be close to the glacier surface, suggesting some throttling in the drainage system. High ablation rates (average $6 \mathrm{~mm} \mathrm{~d}^{-1}$, maximum $10 \mathrm{~mm} \mathrm{~d}^{-1}$ ) were measured during the 2 weeks before the flood events. High-intensity rainfall (maximum $4.4 \mathrm{~mm} \mathrm{~h}^{-1}$ ) commenced at $1700 \mathrm{~h}$ on $15 \mathrm{July}$, petering out by midnight.

\section{The overflow event of 15 July 1987}

The first flood event of July 1987-the "overflow event" - occurred at $2150 \mathrm{~h}$ on $15 \mathrm{July}$, when a loud crash was heard both in the village of Arolla, about $2 \mathrm{~km}$ 

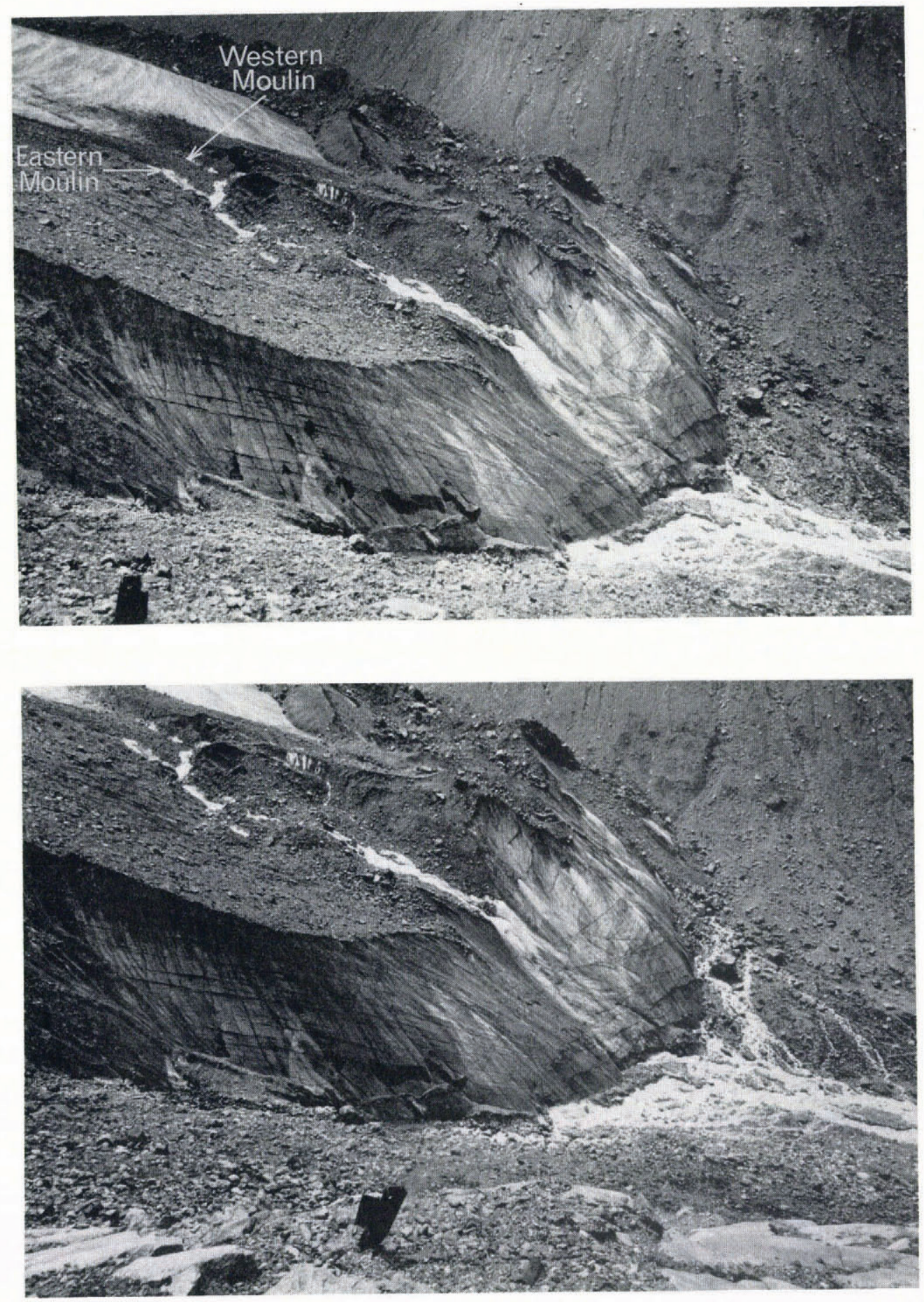

Fig. 4. Rapid shifts in drainage associated with discharge surges from the Bas Glacier d'Arolla during the Fuly 1987 event. The two photographs were taken 25 min apart, at $1425 \mathrm{~h}$ (upper) and $1450 \mathrm{~h}$ (lower) on $16 \mathrm{July} 1987$. The supraglacial overflow channel can be seen as a thread of white ice running through the moraine cover to the snout.

away, as well as in the field camp, sited $500 \mathrm{~m}$ from the glacier. From 2150 to $2220 \mathrm{~h}$, large volumes of water were observed flowing over the snout of the glacier. Flow emerging from the portal subglacial stream fell during this half-hour period, being small in relation to that flowing over the snout (ratio approximately $3: 1$ overflow to underflow), and then returned to its former level. The peak flow of the event was over the $5 \mathrm{~m}^{3} \mathrm{~s}^{-1}$ design capacity of the Grande Dixence flow gauge (to prevent damage to underground installations, flow is automat- ically diverted away from the stage recorder when flow reaches $5 \mathrm{~m}^{3} \mathrm{~s}^{-1}$ ). Flow prior to the event was around $3.75 \mathrm{~m}^{3} \mathrm{~s}^{-1}$.

The event caused significant geomorphological changes in the proglacial zone. Supraglacial moraine carried over the snout of the glacier by the overflow was initially dumped in a large cone in front of the snout (this probably caused the loud crash at the start of the event). This debris, together with large quantities of ice from the margins of the glacier, was then transported downstream. 


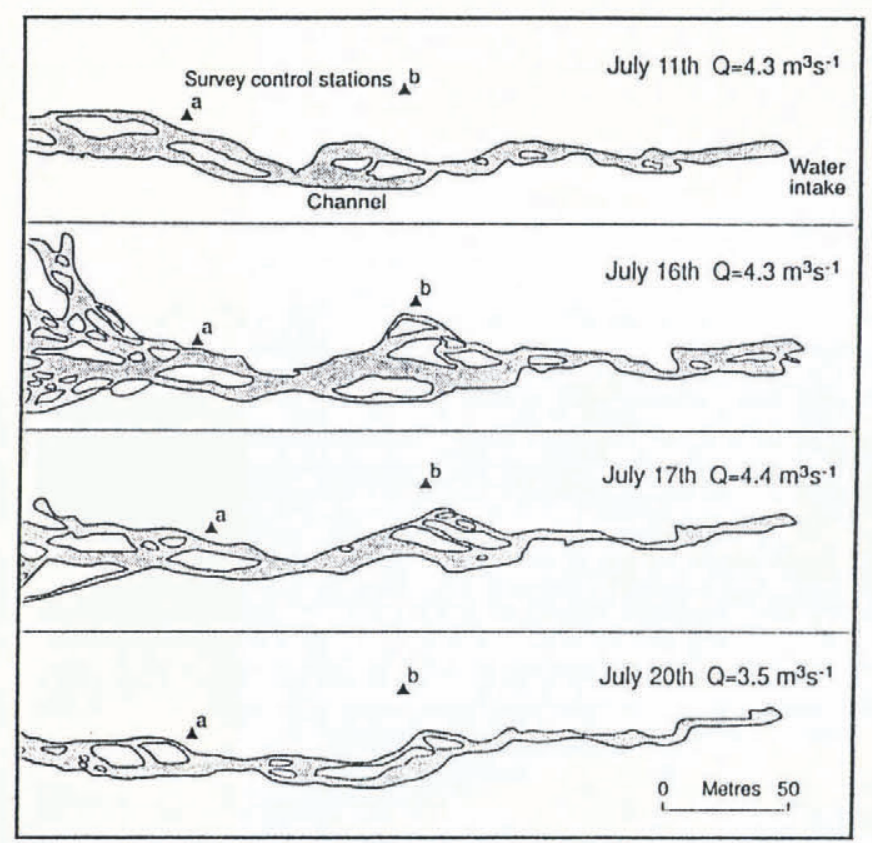

Fig. 5. Changes in the channel pattern of the Bas Glacier d'Arolla proglacial stream in the period 11-20 July 1987. The channels were mapped from oblique photographs. Points $a$ and $b$ are survey stations.

Boulders (500-600 mm diameter) set in a cobbly, gravelsand matrix were purged from the Grande Dixence sediment trap in an almost continuous sequence during the night of 15-16 July (and during the following $5 \mathrm{~d}$ ). Suspended-sediment concentrations, determined from hand samples collected from the main channel during the flood were very high (31 108-39476 $\mathrm{mg} \mathrm{l}^{-1}$ ) in comparison to the mean concentration for the ablation season ( $1200 \mathrm{mg} \mathrm{l}^{-1}$; concentration estimated from a calibrated turbidity record). The ratio of bed load to suspendedsediment load transported during the overflow event was approximately $1: 1$. Electrical conductivity rose from around $13 \mu \mathrm{S} \mathrm{cm}^{-1}$ before the event to around $18 \mu \mathrm{S} \mathrm{cm}^{-1}$ during the event, then fell abruptly to around $10 \mu \mathrm{S} \mathrm{cm}^{-1}$ immediately after the event (Fig. 3).

\section{The high flow period of 16-18 July 1987}

Rain continued to fall during 16 and 17 July but at much reduced intensities. Flow remained high but variable during the $4 \mathrm{~d}$ following the overflow event (Fig. 3). Discharge on 16 July (approximately $3.6-4.6 \mathrm{~m}^{3} \mathrm{~s}^{-1}$ ) was generally much less than the overflow peak, but surges of flow around 5 min duration occurred throughout the day. Throughout 16 July, flow was observed surging out from the glacier along new outflow channels on either side of the central portal stream (Figs 4 and 5). During the afternoon of $16 \mathrm{July,}$ several discharge surges (e.g. increases from 4.11 to $4.44 \mathrm{~m}^{3} \mathrm{~s}^{-1}$ in $5 \mathrm{~min}$ ) and sediment pulses (e.g. increases in suspended-sediment concentration from 950 to $1600 \mathrm{mg} \mathrm{l}^{-1}$ ) occurred. These events involved flow along an increasing number of marginal channels (especially on the western side of the glacier). The marginal streams were seen to be dry at $0730 \mathrm{~h}$ on 17 July, but were carrying flow by $0940 \mathrm{~h}$. By the afternoon of $17 \mathrm{July}$, the duration of the flow surges had increased to around $15 \mathrm{~min}$.
Throughout this period, the main proglacial stream switched from braiding to down-cutting modes in response to the surges in discharge. Considerable erosion of channels close to the glacier occurred, mainly as a result of the collapse of banks of unconsolidated material. Electrical conductivity remained low (at $10 \mu \mathrm{S} \mathrm{cm}^{-1}$ ) during the first part of 16 July then rose to around $15 \mu \mathrm{S} \mathrm{cm}^{-1}$.

\section{The subglacial event of 18 July 1987}

The subglacial flood which occurred at around $1000 \mathrm{~h}$ on 18 July 1987 was the largest of the sequence, and caused the greatest difficulties for Grande Dixence S.A. (not least because it occurred on a Saturday). The peak flow during the event is estimated (by timing floats in the Grande Dixance S.A. weir) to have been around $10 \mathrm{~m}^{3} \mathrm{~s}^{-1}$. This is about three to four times greater than the $2.45 \mathrm{~m}^{3} \mathrm{~s}^{-1}$ flow listed as a "minimal outburst" from Bas Glacier d'Arolla in Haeberli's (1983) review of floods from Swiss glaciers. Heavy rain storms occurred throughout 18 July then declined during 19 July. Flows remained high throughout the weekend and thereafter declined to pre-flood levels (Fig. 3).

High rates of sediment transport and channel change occurred during this final flood event. The sluices on the Grande Dixence S.A. sediment trap were kept open throughout the event. Large ice slabs (the largest having dimensions of $a=1.5 \mathrm{~m}, b=0.7 \mathrm{~m}, c=0.3 \mathrm{~m}$ ) were imbricated in the valley train. The pattern of channel change involved initial widening and braiding followed by down-cutting and a transition to a single thread of dominant flow (Fig. 5). Electrical conductivity readings during the event were sparse (due to equipment breakage) but were around a relatively high $16 \mu \mathrm{S} \mathrm{cm}^{-1}$.

\section{Observed changes on and around the glacier}

Observations made on the lower part of the glacier on 16 July revealed the presence of a suite of freshly developed features.

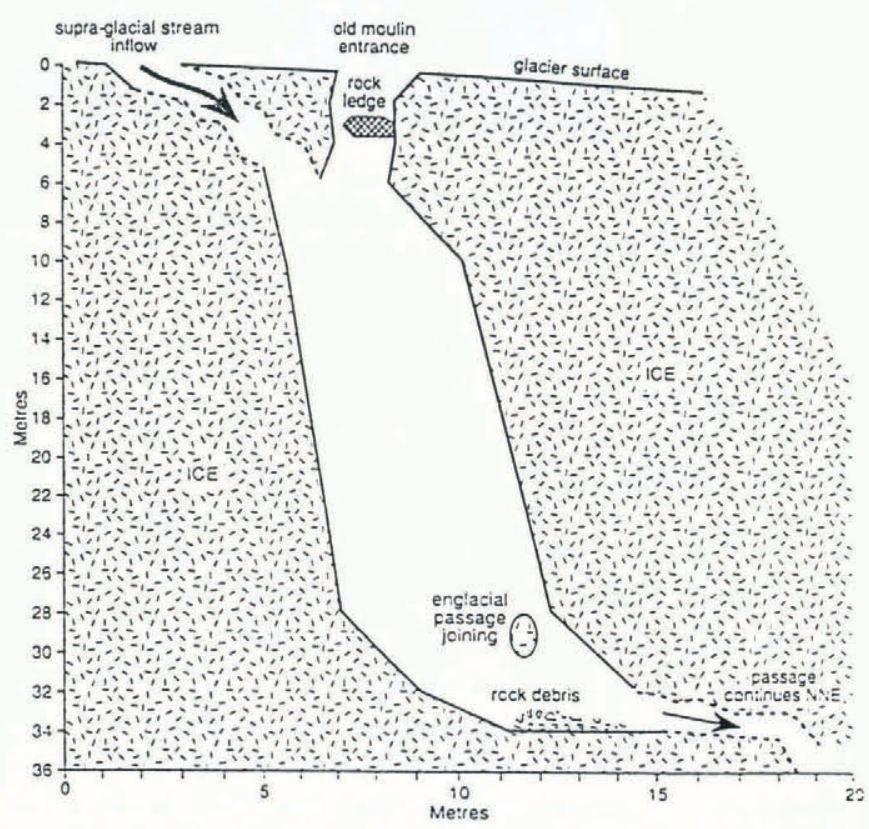

Fig. 6. The internal morphology of the eastern moulin. Measurements were made during a controlled abseil descent. 

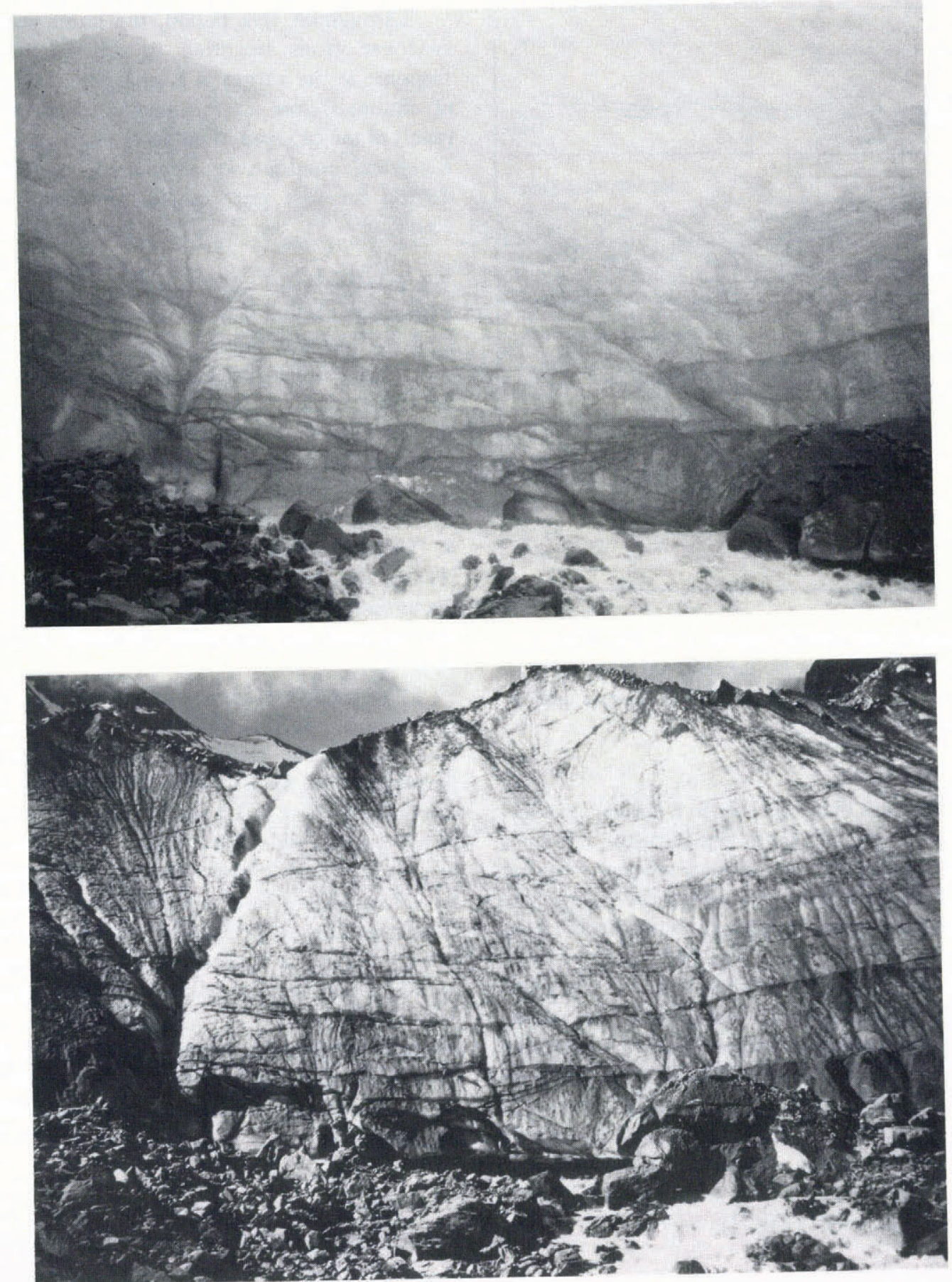

Fig. 7. Photographs of the snout of Bas Glacier d'Arolla before and after the subglacial outburst of 18 July 1987. Upper photograph taken at $0930 \mathrm{~h}, 18 \mathrm{July} 1987$; lower photograph taken at $1030 \mathrm{~h}, 19 \mathrm{July}$ 1987. Note the increase in distance between the glacier sole and the debris bed.

Morphologically altered moulins

Measurements of the internal geometry of the major moulins on Bas Glacier d'Arolla had been made in the 3 weeks prior to the flood events. Measurements made on 16 July showed that the two moulins located in the central valley of the lower tongue of the glacier were both considerably altered. The more westerly of the two had been cleared of the debris which hitherto had choked its shaft. The more easterly moulin had developed a new surface outlet $3 \mathrm{~m}$ downstream of its previous stream entry point (Fig. 6); this could have been the entry point to the moulin in the previous ablation season. Both moulins had clear wash lines on their walls well above supraglacial stream entry levels.
A new ice-cut channel leading from the moulins to the snout A new channel cut into the surface of the glacier, running from the eastern moulin through the moraine of the lower tongue of the glacier to and over the snout had also been created (see Fig. 4). An ice-cut channel running from the lower lip of the western moulin joined this main channel. The channel was measured as $139 \mathrm{~m}$ in length, from 2.5 to $13.8 \mathrm{~m}$ in width, from 0.3 to $0.9 \mathrm{~m}$ in depth and from $4^{\circ}$ to $25^{\circ}$ in slope.

\section{Fissuring of the glacier surface}

A set of arcuate fractures running across the glacier (concave to the snout) had also been created. The fractures were spaced $4-10 \mathrm{~m}$ apart and were up to 
$10 \mathrm{~cm}$ wide. One fracture, $25 \mathrm{~m}$ downstream of the eastern moulin, ran across the full width of the glacier. The fractures tended to focus on the two large moulins described above. The largest concentration of fractures occurred on the eastern side of the glacier. The front face of the glacier also appeared to have bulged out during the event.

All of the above features were observed on the day following the overflow event. Observations made before, during and after the subglacial event of 18 July suggested that the separation distance between the glacier sole and the underlying rock bed increased during the 18 July flood (Fig. 7).

\section{CENTRAL QUESTIONS}

The events at Bas Glacier d'Arolla during the July 1987 floods have parallels in the behaviour of a number of other glaciers displaying spring-event, outburst or surgetype behaviour (Table 1). The Bas Arolla floods also meet most of the criteria listed by Röthlisberger and Lang (1987) as pre-conditions for outburst activity - a need for a restricted englacial and subglacial drainage network, extreme melt rates, storm precipitation and water storage in a glacier-surface snow cover. That the peak discharge of the 1987 outburst (around $10 \mathrm{~m}^{3} \mathrm{~s}^{-1}$ ) was about threefour times greater than that of the event cited as a minor outburst by Haeberli (1983) is in itself noteworthy. The overflow event also marks the 1987 Bas Arolla outburst as unusual. The rapid changes from overflow to distributed then arterial underflow drainage makes the flood behaviour at Bas Arolla particularly unusual.

Table 1. Similarities between the circumstances observed at Bas Glacier d'Arolla during the Fuly 1987 floods and those reported for other glaciers

\section{Glaciers Bas Stor- Variegated Unteraar Findelen Arolla glaciären}

\begin{tabular}{|c|c|c|c|c|c|}
\hline $\begin{array}{c}\text { High water } \\
\text { pressures }\end{array}$ & $*$ & * & $*$ & * & * \\
\hline $\begin{array}{l}\text { Travelling } \\
\text { waves }\end{array}$ & $*$ & * & * & * & \\
\hline $\begin{array}{l}\text { Cracking } \\
\text { of ice }\end{array}$ & $*$ & * & * & * & * \\
\hline $\begin{array}{l}\text { Uplift of } \\
\text { snout }\end{array}$ & $*$ & * & & * & * \\
\hline $\begin{array}{l}\text { Drainage } \\
\text { shifts }\end{array}$ & $*$ & * & * & & \\
\hline $\begin{array}{l}\text { Upwelling } \\
\text { in moulins }\end{array}$ & * & * & * & & \\
\hline
\end{tabular}

\section{Sources}

Storglaciären: Holmlund and Hooke (1983); Variegated Glacier: Kamb and others (1985); Unteraargletscher: Iken and Bindschadler (1986); Findelengletscher: Iken and Bindschadler (1986).
A satisfactory explanation for the observed sequence of flood events at Bas Glacier d'Arolla during 15-19 July 1987 must clearly account for:

(a) The hydrology and hydraulics of the initial overflow flood: was it due to a bottom-up or a topdown overfilling of the moulins? In either case, why was bottom outlet not achieved?; did the excess water come from the rain storm alone, or from stored water as well?; why did the event subside so quickly?

(b) The causes of the morphological changes on the lower tongue of the glacier.

(c) The hydrology and hydraulics of the subglacial drainage shifts and the final subglacial flood: why should bottom outlet be restricted initially (during the overflow event) but then become possible?; what caused the observed switches in the pattern of drainage?; was the main flood an outburst?

\section{RELEVANT THEORY}

The theory relevant to explaining glacier-flood behaviour - that relating to the hydrology and hydraulics of subglacial drainage systems - has developed considerably in recent years, in line with the recognition that glacier-bed hydraulics provide the key to the solution of many of the outstanding problems in glaciology (e.g. the flow of glaciers, the surging of glaciers and the erosion and deformation of glacier beds). The principal concepts of relevance are those of the spring event (Röthlisberger and Lang, 1987), the hydraulic decoupling ("jacking") of glaciers from their beds (Iken, 1981; Iken and Bindschadler, 1986), the linked cavity and conduit model of subglacial drainage (Kamb, 1987) and the flow of water through englacial and subglacial pipes (Röthlisberger, 1972).

Water discharge and pressure fluctuations are of central importance in all of these concepts. Given an hydraulically tight bed situation, a rapid increase in the supply of water to restricted basal cavities or conduits can cause basal water pressures to overcome ice-overburden pressures and result in "hydraulic jacking" of the glacier (Iken, 1981; Iken and Bindschadler, 1986; Röthlisberger and Lang, 1987). This separation facilitates elevated motion of the glacier (surge-like behaviour) (Kamb and others, 1985; Sharp, 1988), changes in the structure of the subglacial system (Kamb, 1987) and the conveyance of accumulated water (outbursts, mini-floods) (Kamb and others, 1985; Humphrey and others, 1986). It may also be associated with seismicity and ice-quake activity at the bed, and fissuring of the ice mass in general (Holmlund and Hooke, 1983; Röthlisberger and Lang, 1987). The conveyance of water downstream is accompanied by a fall in water pressure in the initally affected zone (whence recoupling of the glacier and its bed occurs) and a rise in water pressure down-glacier. Thus, a travelling wave of high water pressure may move down-glacier, causing glacier-bed decoupling as it arrives and recoupling in its wake.

The term "spring event" has been coined to describe 
the first flood of the melt season associated with the regeneration of the englacial and subglacial drainage system and the discharge of accumulated meltwaters (Röthlisberger and Lang, 1987). In this case, the high water pressures result from the input of meltwaters into a drainage system whose capacity has degenerated under ice-pressure closure over winter (Shreve, 1972; Hooke and others, 1985). Hydraulic surcharging may also be produced by the input of water from exceptionally high ablation, heavy storm rainfall or the rupture of englacial or subglacial water pockets. These events are not confined to the early part of the ablation season. The term "outburst" is generally used to define glacier floods associated with the release of water stored within, on or around the glacier (Haeberli, 1983). "Glacier flood" is a generic term for all high-magnitude floods from glaciers, irrespective of their origin.

\section{PREFERRED EXPLANATIONS FOR THE FLOOD EVENTS AT BAS GLACIER D'AROLLA, 15-19 JULY 1987}

Finding answers to the questions posed in section 2 amounts to a reconstruction of the events. Given the unexpected nature of the event, we have to judge what we believe to be the most plausible explanations for the observed phenomena.

\section{The overflow event of 15 July 1987}

\section{Top-down or bottom-up surcharging?}

Three lines of evidence support the hypothesis that the surcharging of the moulins during the overflow event was due to a bottom-up rather than a top-down filling process. The first of these lies in the discharge capacity of the supraglacial channel system above and below the moulins. Measurements of the slope and channel capacity of the supraglacial streams running into (from upstream) and out of (downstream from) the moulins were made after the floods had subsided. The capacity of the channel downstream of the moulins is much greater than would be expected were the waters responsible for carving the downstream channel to have passed through the up- stream channel network (Fig. 8). Abney level surveying of the slope of the channel upstream of the moulins indicates slopes in the range $4-7^{\circ}$, while the channel below the moulins (but above the front face of the glacier) has slopes ranging from $4^{\circ}$ to $25^{\circ}$. The conveyance potential of the downstream channel is thus much greater than that of the upstream channel, to a degree which is not consistent with the supraglacial conveyance of supraglacial waters into and beyond the moulins. A flow input from the moulins is implied.

The observed increases in both suspended-sediment concentration and electrical conductivity also support a bottom-up surcharge hypothesis. A top-down supply would require the suspended-sediment load to be derived from the proglacial zone (given the paucity of fines on the glacier surface). While it is known that some fines are derived from the proglacial zone (especially during extreme flood events), the overwhelming majority are known to be derived from subglacial sources (Gurnell and Warburton, 1990). Whilst unremarkable in itself, the observed rise in electrical conductivity during the overflow event (from 13 to $18 \mu \mathrm{S} \mathrm{cm}^{-1}$ ) is also consistent with the release of subglacial as opposed to supraglacial waters.

The third line of evidence in support of a bottom-up over a top-down filling hypothesis lies in the higher likelihood for water being stored within the glacier (in the conduit system, in bed cavities or in water pockets) than on top of it (the snowpack would have been the only possible water source or store).

Our conclusion is therefore that the overflow event was caused by an upwelling, and subsequent overspill, of water in the portal-area moulins. Similar rises of water in moulins have been reported for Storglaciären, Sweden, where water levels reaching $80 \%$ of moulin depth have been observed on numerous occasions, and one case of a rise to $97 \%$ of moulin depth has been reported (Holmlund and Hooke, 1983). Geyser-like spouts of water issuing from vertical fissures on glaciers in Spitsbergen, Greenland and Switzerland have also been documented (Baranowski, 1973).

We can evaluate the water pressure needed to drive flow up the Bas Glacier d'Arolla moulins as follows. Treated as a problem in hydrostatics, and ignoring

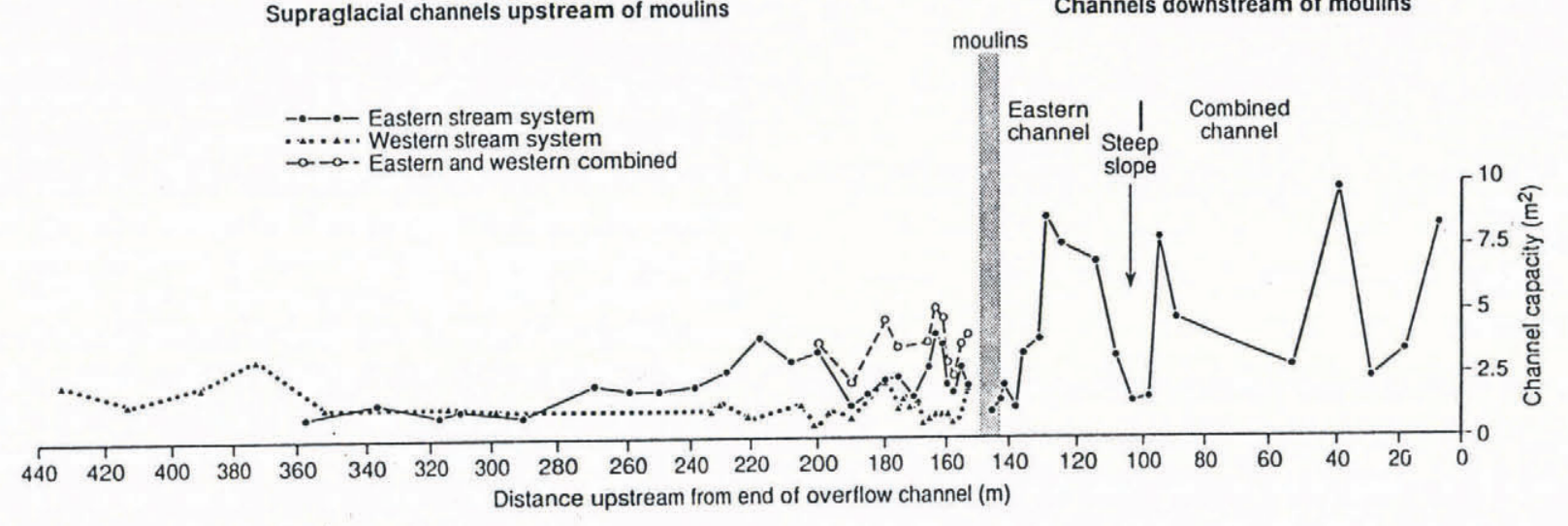

Fig. 8. Channel capacity (cross-section area) of the supraglacial stream system upstream of the moulins and the overflow channel system downstream of the moulins. 
viscosity effects, the water pressure $\left(P_{\mathrm{w}}\right)$ at the base of a steeply inclined shaft of constant diameter and height $h$ is given by:

$$
P_{\mathrm{w}}=w g h
$$

where $w$ is the density of water $\left(1000 \mathrm{~kg} \mathrm{~m}^{-3}\right)$ and $g$ is acceleration due to gravity $\left(9.81 \mathrm{~m}^{-1} \mathrm{~s}^{-2}\right)$. On the evidence of valley and glacier geometries, and data from seismic surveys (Knecht and Susstrunk, unpublished) and thermal probing studies (personal communication from A. Bezinge), $60 \mathrm{~m}$ would appear to be an appropriate value to take for glacier thickness in the vicinity of the moulins. On being filled, the water pressure at the base of the moulins would hence be $0.59 \mathrm{MPa}$. A water pressure of over $0.6 \mathrm{MPa}$ is thus implied for the overflow event.

\section{Source of the excess water}

For such a short-lived $(30 \mathrm{~min})$, high water-pressure $(>0.6 \mathrm{MPa})$ episode to occur, there must have been a sudden arrival of water in large quantities. This could have resulted from the rupture of a stored water pocket, or could have marked the arrival of a travelling wave of high water pressure, of the type monitored on Storglaciären by Holmlund and Hooke (1983). Both hypotheses appear plausible. The 1974 minor outburst from Bas Glacier d'Arolla was attributed to the rupture of an internal water pocket. Geophysical surveys of the tongue of the glacier (Knecht and Susstrunk, unpublished) revealed a topographic low near the snout. The relatively low conductivities recorded during the event are, however, inconsistent with the release of water held long term in a subglacial store. The travelling-wave hypothesis appeals in view of the high melt rates of the previous fortnight, the heavy rainfalls of the previous $5 \mathrm{~h}$ and the retarded state of the englacial drainage network. Given that the rainfall was able to make its way to the bed of the glacier in the upper area of the glacier tongue, it could have augmented water held in the conduit-cavity system, raising water pressures to supercritical levels, causing local bed separation, further integrating the drainage system and thence initiating a growing wave of high water pressure moving down-glacier (cf. Holmlund and Hooke, 1983). On balance, we prefer to think of the source of water for the overflow event in terms of the addition of recent rain and snowmelt waters to accumulated meltwaters held in an hitherto poorly integrated subglacial drainage system.

Why was bottom outlet not achieved during the overflow event, yet was thereafter?

The rise of water in the moulin shafts must have been a response to surcharging of the subglacial conduit system. The maintenance of some flow from the main portal stream during the overflow event, and the subsequent reversion to subglacial flow about $30 \mathrm{~min}$ later, implies that the subglacial outlet was partially and temporarily blocked (e.g. by localized roof collapse, by general ice collapse or by accumulation of debris). Were blockage not to have occurred, the head-discharge effect would have driven higher than normal flows through the subglacial stream. This was not the case (subglacial flows fell during the overflow event). The restriction responsible for causing water to be forced up the moulins rather than out through the portal conduit was thus probably a combination of limited hydraulic capacity and partial conduit blockage. The rise of waters in the moulins and the subsequent overspill would have coped with the initial peak of the flood, and could have forced the removal of any temporary blockage in the subglacial conduit system. An alternative explanation for the short-lived nature of the overflow event is that the high water pressures generated were able to cause ice-bed separation (hydraulic jacking), which facilitated the resumption of subglacial flow. The fracturing of the ice in the snout zone is good evidence for displacement at the snout but does not necessarily mean that the glacier was moved upwards and forwards. However, the question as to whether or not hydraulic jacking could have taken place at Bas Glacier d'Arolla merits discussion.

\section{Could hydraulic jacking have occurred?}

The critical water pressure $\left(P_{\mathrm{c}}\right)$ needed to achieve uplift under model bed conditions has been defined by Iken (1981), and applied by Röthlisberger and Iken (1981) and Iken and others (1983). The critical water pressure for uplift becomes smaller as the slope of the bed $(\alpha)$ increases and the reverse slope of undulations or steps on the bed $(\psi)$ decreases (Röthlisberger and Iken, 1981). Ice-overburden pressure $\left(P_{\mathrm{o}}\right)$ is given by:

$$
P_{\mathrm{o}}=i g h \cos \alpha
$$

where $i$ is the density of ice, $g$ is acceleration due to gravity, $h$ is mean thickness of glacier ice and $\alpha$ is the mean surface slope. The critical water pressure $\left(P_{c}\right)$ for translatory displacement is then given by:

$$
P_{\mathrm{c}}=P_{\mathrm{o}}-\left(\tau_{\mathrm{b}} / \tan (\alpha+\psi)\right)
$$

where $\tau_{\mathrm{b}}$ is basal shear stress $\left(\tau_{\mathrm{b}}=i g h \sin \alpha\right.$, or, taking

Table 2. Overburden pressure $\left(P_{\mathrm{o}}\right)$, basal shear stress $\left(\tau_{\mathrm{b}}\right)$ and critical water pressure $\left(P_{\mathrm{c}}\right)$ calculations for bed slopes $(\alpha)$ of $2^{\circ}, 5^{\circ}$ and $10^{\circ}$, under an ice thickness of $60 \mathrm{~m}$ and $a$ bed step/undulation dip $(\psi)$ of $2^{\circ}$

\begin{tabular}{lcll}
\hline & $\begin{array}{c}\alpha=2^{\circ} \\
\psi=2^{\circ}\end{array}$ & $\begin{array}{l}\alpha=5^{\circ} \\
\psi=2^{\circ}\end{array}$ & $\alpha=10^{\circ}$ \\
& $\psi=2^{\circ}$ \\
Overburden pressure (Po & 0.541 & 0.539 & 0.533 \\
\hline
\end{tabular}

A. Ignoring the effect of valley walls

$\begin{array}{llll}\text { Basal shear stress }\left(\tau_{\mathrm{b}}\right) & 0.019 & 0.047 & 0.094\end{array}$

Critical water pressure $\left(P_{\mathrm{c}}\right) \quad 0.270 \quad 0.155 \quad 0.090$

$P_{\mathrm{c}}$ as per cent of $P_{\mathrm{o}} \quad 50 \% \quad 29 \% \quad 17 \%$

B. Incorporating effect

of valley walls $(f=0.75)$

$\begin{array}{llll}\text { Basal shear stress }\left(\tau_{\mathrm{b}}\right) & 0.014 & 0.035 & 0.071\end{array}$

Critical water pressure $\left(\begin{array}{llll}\left.P_{\mathrm{c}}\right) & 0.338 & 0.251 & 0.202\end{array}\right.$

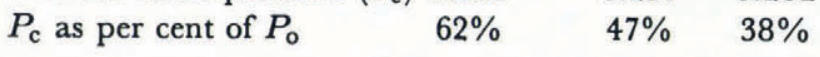

Note. All pressure values expressed in $\mathrm{MPa}$. 
account of valley-wall effects, $\tau_{\mathrm{b}}=f i g h \sin \alpha ; f$ is a shape factor (Paterson, 1981)) and $\psi$ is the backward tilt angle of steps forming an undulatory hard bed. To apply the model to the snout zone of Bas Glacier d'Arolla, we need to provide values for $h, \alpha$ and $\psi$. We have previously determined $60 \mathrm{~m}$ to be an appropriate value for $h$. Table 2 shows evaluations of overburden pressure $\left(P_{\mathrm{o}}\right)$, basal shear stress $\left(\tau_{\mathrm{b}}\right)$ and critical water pressure $\left(P_{\mathrm{c}}\right)$ for a range of realistic bed-slope angles, assuming the presence of bed steps or undulations with a backward slope angle $(\psi)$ of $2^{\circ}$ (implying a gently undulating hard bed). The upper set of values neglects valley-side effects upon $\tau_{\mathrm{b}}$; the lower set incorporates this effect, assuming a value of 0.75 for $f$. It would seem that a water pressure of around $0.25 \mathrm{MPa}$ would be sufficient to cause hydraulic jacking of the glacier, were the assumptions of the model satisfied. The model defines a rigid, undulating bed with free water access to all points on the bed. The properties of the bed at Bas Glacier d'Arolla, as far as they are known, do not conform to these assumptions especially well. The rock bed is covered by a layer of unconsolidated glacial sediments (Knecht and Susstrunk, unpublished). Were this to be in a frozen or semi-frozen state, as is thought to be the case for many glaciers in the Valais region of Switzerland (Haeberli and others, 1989), or were the till/rock bed to be hydraulically sealed and saturated, the necessary water pressures for uplift of the snout may still be attainable under circumstances of rapidly increased water supply. We have already noted that for water to be driven $60 \mathrm{~m}$ up a vertical shaft implies the occurrence of a water pressure of over $0.6 \mathrm{MPa}$. Were bed conditions favourable, it would seem that hydraulic jacking would have been possible under the basal water regime existing during the July 1987 flood phase. Despite the fact that the bed at Bas Glacier d'Arolla does not correspond closely to the hard-bed type, it would seem, given the high water pressures, that hydraulic jacking cannot be dismissed as a possible generating mechanism for the resumption of the subglacial drainage after the overflow event (and for the outburst event of 18 July).

The observed fissuring of the lower tongue of the glacier - cause or product of the overflow event?

As noted above, the observed fissuring of the lower tongue of the glacier after the overflow event lends support to the hydraulic jacking hypothesis. Whatever the precise cause of the surcharging of the basal and englacial conduit system during the overflow event, there would have been a rapid rise then fall in water pressures. This would have exerted pronounced loading then unloading stresses on the adjacent ice mass, whether or not uplift occurred (Röthlisberger and Lang, 1987). Such circumstances have been noted to induce icequake activity and surface fracturing on Storglaciären (Holmlund and Hooke, 1983). Were the fissuring of the glacier to have occurred at an early stage during the flood, fracturing of ice could have caused temporary blockage of subglacial conduits. Thus, the overflow event could have been a product of the fissuring. If ice blockage of subglacial channels did occur, high concentrations of ice blocks would have been expelled into the proglacial stream on the resumption of subglacial flow. This was not the case, at this time. On balance, our preference is to regard the fissuring as a product of the high water pressures exerted during the overflow event. Local ice fracturing and blockage of conduits may have occurred, but we do not regard the fracturing as a necessary precursor of the overflow.

\section{The mini-floods and drainage shifts of 16 and 17 July 1987}

Shifts in drainage of the type witnessed at Bas Glacier d'Arolla from 16 to 19 July 1987 are common during large flood events, and the switching of portal positions has been observed on several other Alpine glaciers, e.g. Glacier de Tsidjiore Nouve, Switzerland, and Glacier d'Argentière, France (Röthlisberger and Lang, 1987). The sequence of mini-floods, sediment pulses and marginal drainage shifts observed on 16 and 17 July suggest a poorly developed water system with water being forced along multiple passageways at the bed. The marginal drainage outlets emerged at a higher elevation than the main proglacial portal, implying poor linkage between the central and marginal channel systems. It was only on 18 July, during and after the largest flood of the sequence, that a well-developed arterial conduit system came into operation. The observed sequence of drainage pattern shifts suggests first, that during 16 and 17 July the drainage system took the form of a widely distributed but not fully integrated network; and secondly, that on 18 July a transition occurred to an arterial conduitdominated system. Arterial drainage is likely to be the equilibrium structure at Bas Glacier d'Arolla, because the concave nature of the glacier surface favours the development of a single central conduit (Röthlisberger and Lang, 1987). This theory is supported by observations made in a tunnel cut along the course of the main stream of the glacier in 1950 (Haefeli, 1951). The flood of 18 July is therefore seen as marking the development of the equilibrium drainage structure.

\section{The subglacial flood of 18 July 1987}

The final subglacial outburst was discharged from the central zone of the snout and involved an apparent increase in the distance between the glacier sole and the glacier bed. For this to have occurred, the restriction on portal outflow which existed at the time of the overflow event, about $60 \mathrm{~h}$ earlier, must have been overcome. This could have been achieved via the melting of conduit walls (e.g. Mathews, 1973; Röthlisberger and Lang, 1987), thereby increasing the hydraulic capacity of the portal outlet. The high water pressures and flows experienced both during and after the overflow event would accelerate the melting process. The high water pressures could also have flushed out any debris which may have temporarily accumulated in the portal conduits before the overflow event. Other possibilities also exist:

(a) Erosion of the bed.

(b) Melting/fracture of the basal layer of the glacier.

(c) Hydraulic jacking of the glacier.

Each of these possibilities is consistent with the observed increase in separation distance between the glacier and its bed. Each is now taken in turn. 


\section{Erosion of the bed}

Bas Glacier d'Arolla does not rest on bedrock, but on a rock bed covered by a thick veneer of coarse rock and till (Knecht and Susstrunk, unpublished). Some parts of the veneer are frozen but others are loose. This was confirmed during the August 1987 flood, when an ice-marginal stream scoured the glacier margin and exposed a partially frozen unconsolidated debris bed. Under such circumstances, high interstitial water pressures may substantially decrease sediment shear strength (Boulton, 1979; Drewry, 1986). This effect will be greatest near the margins of the glacier, where sediments can be expected to be less frozen. Debris may thus be efficiently scoured from the bed near the glacier portal (which would explain the observed increase in distance between the ice sole and the debris bed). The high suspended-sediment concent-rations measured during the outburst are also consistent with a bed-sediment removal hypothesis. Bed-material removal is thus a possible explanation for the restoration of subglacial flows, and the increased distance between the glacier and its bed. Close inspection of the photographs shown as Figure 7, however, reveals the same assemblage of boulder-sized materials at the snout of the glacier both before and after the 18 July flood. It would thus appear that any bed erosion was limited to the fine and cobblesized fractions of the rock bed.

\section{Melting/fracture of the basal ice layer}

Large ice slabs were found imbricated in the proglacial river gravels during the course of the subglacial flood, and the under surface of the glacier at the proglacial portal was observed to be heavily scalloped. Inspection of the photographs shown as Figure 7, however, reveals no great change in the characteristics of the basal ice layer of the glacier above the main portal stream. Given that the ice blocks found in the proglacial stream could have been derived from other sections of the drainage system (e.g. ice blockages of conduits), and the scalloping of the glaicer sole could have existed before the flood of $18 \mathrm{July}$, there would seem to be insufficient evidence to explain the ice-bed separation at the snout as a basal-ice removal effect.

\section{Hydraulic jacking}

Hydraulic jacking of the lower zone of the glacier could, in principle, account for both the observed fissuring associated with the overflow event of $15 \mathrm{July}$, and the observed bed separation associated with the subglacial flood of 18 July. The 18 July outburst is estimated to have had a peak discharge of around twice that of the overflow event of $15 \mathrm{July}$, so the critical water pressures required for uplift could have been attained despite the increase in hydraulic capacity of the system likely to have occurred between the two events. Given the inability to explain fully the observed increase in separation in terms of erosion of the bed and/or removal of the basal ice layer, an hydraulic jacking effect must again be upheld as a possible contributing factor.

\section{Source of the water discharged during the 18 July 1987 flood} The outburst of the morning of 18 July preceded the heavy rains of $18 \mathrm{July}$; rainfall in the $24 \mathrm{~h}$ prior to the flood of 18 July was only $4 \mathrm{~mm}$. It thus appears that the outburst flood discharged waters held back in the drainage system.

\section{Preferred explanations for the 18 July 1987 flood}

Taking all evidence together, we hold the view that the event of 18 July was a subglacial outburst of the springevent type. The increase in conveyance was probably achieved by a combination of rock-bed erosion, clearance of ice blocks from portal conduits and, perhaps, some hydraulic jacking. The loose bed characteristics at Bas Glacier d'Arolla do not provide favourable conditions for hydraulic jacking (though given saturation, jacking is not out of the question). There was no obvious forward motion (as would be expected with jacking), and the observations and photographs of ice-bed separation on 18 and 19 July lack the resolution to support a categorical assertion that upward motion did really occur. It seems clear that the subglacial drainage network became rationalized for the first time in the 1987 ablation season on $18 \mathrm{July}$, under the influence of the heavy rainstorms of the period, and that previously stored water was released. This was certainly a "spring event". It may have involved hydraulic jacking; but jacking is not a necessary part of the explanation offered.

\section{CONGLUSIONS}

We have presented a series of observations on a highly unusual sequence of glacier flood events. Our view is that the overflow event described was the product of a bottomup surcharging of a poorly developed subglacial system, and the succeeding subglacial outburst was a particularly dramatic example of the "spring-event" phenomenon. Hydraulic jacking is implicated, but not proven, in both events. High-intensity rainstorms acted as dramatic trigger events, forcing an hitherto retarded hydraulic system into a rationalized state.

We acknowledge the somewhat "speculative" nature of the explanations offered, but believe that we have exposed our hypotheses to as rigorous a testing, albeit of a subjective kind, as was possible in the circumstances. We believe it better to proceed on this basis than not to attempt to explain at all.

\section{ACKNOWLEDGEMENTS}

The field work was undertaken while J.W. held a U.K. Natural Environment Research Council research studentship at the University of Southampton, and C.R.F. was at Worcester College of Higher Education. Discharge data were provided by Grande Dixence S.A. S. Fraser-Clark and P. Gogarty (Worcester College of Higher Education) assisted with the survey of the overflow channel. P. Gogarty also carried out the moulin survey.

\section{REFERENCES}

Baranowski, S. 1973. Geyser-like water spouts at Werenskioldbreen, Spitsbergen. International Association of Scientific Hydrology Publication 95 (Symposium at Cambridge 1969 - Hydrology of Glaciers), 131-133. 
Boulton, G. S. 1979. Processes of glacier erosion on different substrata. $\mathcal{J}$. Glaciol., 23(89), 15-38.

Drewry, D. 1986. Glacial geologic processes. London, Edward Arnold.

Gurnell, A. M. and J. Warburton. 1990. The significance of suspended sediment pulses for estimating suspended sediment load and identifying suspended sediment sources in alpine glacier basins. International Association of Hydrological Sciences Publication 193 (Symposium at Lausanne $1990-$ Hydrology in Mountainous Regions. I. Hydrological Measurements; the Water Cycle), 463-470.

Haeberli, W. 1983. Frequency and characteristics of glacier floods in the Swiss Alps. Ann. Glaciol., 4, 85-90.

Haeberli, W., P. Müller, P. Alean and H. Bösch. 1989. Glacier changes following the Little Ice Age - a survey of the international data basis and its perspectives. In Oerlemans, J., ed. Glacier fluctuations and climatic change. Dordrecht, etc., Kluwer Academic Publishers, 77-101.

Haefeli, R. 1951. Some observations on glacier flow. f. Glaciol., 1(9), 496-500.

Holmhund, P. and R. LeB. Hooke. 1983. High water-pressure events in moulins, Storglaciären, Sweden. Geogr. Ann., 65A(1-2), 19-25.

Hooke, R. LeB., B. Wold and J. O. Hagen. 1985. Subglacial hydrology and sediment transport at Bondhusbreen, southwest Norway. Geol. Soc. Am. Bull., 96(3), 388-397.

Humphrey, N., C. Raymond and W. Harrison. 1986. Discharges of turbid water during mini-surges of Variegated Glacier, Alaska, U.S.A. 7. Glaciol., 32(111), 195-207.

Iken, A. 1981. The effect of the subglacial water pressure on the sliding velocity of a glacier in an idealized numerical model. F. Glaciol., 27(97), 407-421.

Iken, A. and R.A. Bindschadler. 1986. Combined measurements of subglacial water pressure and surface velocity at Findelengletscher, Switzerland: conclusions about drainage system and sliding mechanism. F. Glaciol., 32(110), 101-119.

Iken, A., H. Röthlisberger, A. Flotron and W. Haeberli. 1983. The uplift of Unteraargletscher at the beginning of the melt season - a consequence of water storage at the bed? $\mathrm{F}$. Glaciol., 29(101), 28-47.

Kamb, B. 1987. Glacier surge mechanism based on linked cavity configuration of the basal water conduit system. F. Geophys. Res., 92(B9), 9083-9100.

Kamb, B. and 7 others. 1985. Glacier surge mechanism: 1982-83 surge of Variegated Glacier, Alaska. Science, 227(4686), 469-479.

Knecht, H. and A. Süsstrunk. Unpublished. Bericht uber die seismische Sondierung des Glaciers du Mont Collon, Juli 1949. Report for Grande Dixence S.A., Sion, Valais, Switzerland.

Mathews, W.H. 1973. Record of two jökullhlaups [sic]. International Association of Scientific Hydrology Publication 95 (Symposium at Cambridge 1969 - Hydrology of Glaciers), 99-110.

Naef, F., W. Haeberli and M. Jaggi. 1989. Morphological changes in the Swiss Alps resulting from the 1987 summer storms. In Starosolszky, O. and O.M. Melder, eds. Hydrology of disasters. London, James and James, 36-42.

Paterson, W. S. B. 1981. The physics of glaciers. Second edition. Oxford, etc., Pergamon Press.

Rey, Y. and G. Dayer. 1990. Crues de l'été 1987 dans les bassins versants glaciaires des Alpes Pennines. Reoue Géogr. Alp., 78(1-3), 115-124.

Röthlisberger, H. 1972. Water pressure in intra- and subglacial channels. F. Glaciol., 11(62), 177-203.

Rothlisberger, H. and A. Iken. 1981. Plucking as an effect of waterpressure variations at the glacier bed. Ann. Glaciol., 2, 57-62.

Röthlisberger, H. and H. Lang. 1987. Glacial hydrology. In Gurnell, A.M. and M.J. Clark, eds. Glacio-fluvial sediment transfer: an alpine perspective. Chichester, etc., John Wiley and Sons, 207-284.

Sharp, M. 1988. Surging glaciers: behaviour and mechanisms. Prog. Phys. Geogr., 12(3), 349-370.

Shreve, R. L. 1972. Movement of water in glaciers. F. Glaciol., 11(62), 205-214.

Warburton, J. 1990. An alpine proglacial fluvial sediment budget. Geogr. Ann., 72A(3-4), 261-272.

The accuracy of references in the text and in this list is the responsibility of the authors, to whom queries should be addressed. 